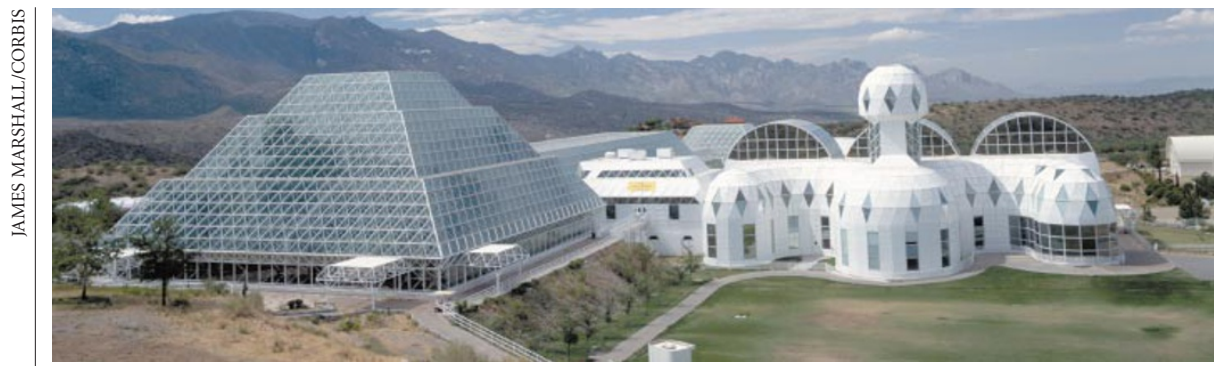

Respectability beckons: Biosphere 2 is 'on the border' of being a fully functioning scientific facility.

\title{
Columbia extends support for 'mainstream' Biosphere 2
}

Tucson, Arizona

Columbia University in New York is poised to extend its agreement to manage the controversial Biosphere 2 centre in Arizona for a further ten years. After a rocky start, the centre is claimed to be on the threshold of becoming a recognized scientific facility.

Columbia's trustees were due to meet this week to consider university president George Rupp's recommendation to keep on running Biosphere 2 as a 'Columbia West' facility. The trustees are expected to approve the agreement, which was worked out a year earlier than had been anticipated.

Since taking over management of Biosphere 2 in 1996, Columbia has worked to turn the centre, created as an experimental, self-contained environment, into a mainstream educational and scientific facility (see Nature 378, 223; 1995 \& 380, 275; 1996).

Increasing student enrolment confirms the success of the educational mission. But scientific success has been more elusive, because of the complexities of revamping and staffing the facility outside Tucson which includes a saltwater lagoon, a tropical forest and carbon dioxide experiments with 50-foot-tall trees.

"It took us two years longer than we hoped, but we have turned the corner scientifically," says Michael Crow, an environmental scientist and Columbia's executive viceprovost, pointing to the budding number of publications emerging from the facility.

Last week, scientists and officials from the US Department of Energy visited Biosphere 2 as part of the centre's efforts to attract federal funding. Discussions are under way with the Los Alamos National Laboratory to conduct experiments in Biosphere 2's controlled environment. And a biodiversity research programme is being created outside the structure near Oracle, Arizona, to study the high-desert region.

"Things are moving quickly now" to meet the facility's scientific goals, says William Harris, a former assistant director at the National Science Foundation who has run Biosphere 2 since late 1996.
Joe Berry, a biologist at the Carnegie Institute at Stanford University who is one of three scientists overseeing projects at Biosphere 2, says the operation is "on the border" of being a fully functioning scientific facility "We have been doing the easy experiments," Berry says. "We have not done the hard ones yet."

Berry, who has been setting up experiments on mass balance in terrestrial ecosystems, says that implementing proper controls in the cavernous environmental lab has been extremely challenging. For example, raising Biosphere 2's internal monitoring equipment to the required standards involved major reassessments.

When Columbia took over, Biosphere 2 had about 700 sensors buried and placed around its different habitats and connected to computers. But the new team didn't know where they all were or what they did. Eventually a revised monitoring system using about 70 sensors was devised.

Throughout the four-year 'proof-ofconcept' period since Columbia took over, Biosphere has continued to receive financial support from Edward Bass, the Texas billionaire who built the facility to explore his environmental visions. According to his associate, Martin Bowen, Bass is "very, very satisfied with the management and accomplishments" of Columbia.

Since Columbia took over, university records show that Bass has given Biosphere 2 about \$10 million per year (according to its tax returns, the centre has an annual operating budget of nearly $\$ 12$ million). The records say he plans to contribute $\$ 30$ million during the next five years.

About 100 undergraduate students come to Biosphere 2 from Columbia and more than 20 partner universities, paying Columbia about $\$ 12,000$ per semester. Researchers, such as Columbia's Wallace Broecker, say the courses have been very popular.

Once the new agreement is finalized, Harris says new staff will be appointed, the student population expanded to 300 , and a masters' programme developed. Rex Dalton

\section{US trade rules seek to balance health and patent protection}

\section{Washington \& Cape Town}

The US administration is relaxing its approach to developing countries seeking affordable medicines during public health crises. The move follows protests that Vice-President $\mathrm{Al}$ Gore and trade officials put pressure on South Africa to alter a 1997 law — aimed at combating its AIDS crisis - that allows the cheap manufacture or import of patented drugs (see Nature 399, 717; 1999).

Speaking at the World Trade Organization (WTO) meeting in Seattle last week, US President Bill Clinton said that US trade officials will in future consider the public health conditions of developing countries, as well as intellectual property law, in making trade decisions involving medicines.

Specifically, the office of the United States Trade Representative (USTR) will confer with the Department of Health and Human Services when a developing country complains that US trade law is making medicine unaffordable. According to a press release, USTR will "give full weight" to the department's advice on health considerations.

But the administration insists that its policy will not jeopardize the intellectual property rights of US pharmaceutical companies. Charlene Barshefsky, the US trade representative, says that she and health secretary Donna Shalala "believe that sound public health policy and intellectual property protection are, and must continue to be, mutually supportive".

US activists have welcomed the announcement. "It's a big deal," says James Love, director of the Washingtonbased Consumer Project on Technology. "They have reclassified these [situations] as public health issues as opposed to commercial disputes."

A US official says the United States has not changed its interpretation of a key WTO agreement on trade-related intellectual property rights (TRIPs). This allows countries to manufacture or import drugs cheaply, paying only negotiated royalties to the patent holder, only in cases of "national emergency or other circumstances of extreme urgency". South African and US trade officials had disagreed on whether South Africa's law breaches the TRIPs agreement.

The USTR said that South Africa had been removed from a 'watch list' of 
countries threatened with sanctions, partly because of an agreement in which both countries promised to protect intellectual property rights while addressing the health issues.

It is not clear how South Africa could bring its legislation in line with its government's commitment to TRIPs. But Alec Erwin, the country's minister for Trade and Industry, maintains that South Africa has sought no agreement with the US on patent right exhaustion.

This occurs when the patent holder loses control over the further sale of his products, and - unlike parallel importing — is not prohibited by TRIPs. In terms of the treaty, compulsory licensing is permitted at the discretion of individual countries.

Local firms could then be licensed to manufacture goods using another company's patented formula, provided that the patent owner is compensated and the government's action is subject to judicial review. This provision had previously been opposed by the US government, which has reserved the right to pressure countries not to use it.

South Africa has not withdrawn its intention to use parallel imports or compulsory licensing to obtain drugs at lower prices, nor did the US government sanction these practices. But parallel importing remains a likely subject of proposed reform of the South African Medicines and Related Substances

Act. Meredith Wadman \& Michael Cherry

\section{AAAS to honour 'persecuted' Ukranian marine biologist}

\section{London}

Sergei Piontkovski, the Ukrainian marine biologist facing criminal charges over his role in various international research projects, is to be honoured at a reception held annually by the American Association for the Advancement of Science (AAAS) to recognize persecuted scientists.

Piontkovski and colleagues at the Institute of Biology of the Southern Seas in Sebastopol have been under close scrutiny from the local branch of the country's security services - formerly the KGB - since the end of October over their links with the West (see Nature 401, $835 \&$ 402, 6; 1999).

The AAAS's Science and Human Rights Program will host the reception at the association's annual conference in Washington next February. In a letter to Piontkovski, Elisa Muñoz of the AAAS says that "the Program will honor you in recognition of the persecution that you have endured". She adds that AAAS officials "have been following your case and will continue to monitor events with concern".

Initially, Piontkovski faced charges related to espionage and hard currency concerning a number of international science grants. However, he has now been charged with illegal currency operations and organized crime in relation to his handling of project funds paid to him in hard currency. Piontkovski expects court proceedings to start soon, and the case might start in January.

INTAS, the European body that promotes cooperation with scientists from the former Soviet Union, is one of the agencies making payments to Piontkovski, on a project on plankton distribution jointly funded by the Ukrainian Ministry of Science.

INTAS secretary David Gould said last week, "We have agreements of scientific cooperation which clearly state the terms of the contract".

Such terms include the conditions under which payment can be made, and foresee payment in hard currency. INTAS says that, as far as it is aware, currency has been handled in accordance with signed agreements.

INTAS is due to hold a meeting in midJanuary to evaluate bids from newly emerging states for the 1999 funding call. "Clearly, if this is not resolved there could be consequences for the support of projects in Ukraine," says Gould. INTAS says it is continuing its "dialogue" with the science ministry.

Ukraine's president, Leonid Kuchma, has been reported as seeking a sign that Ukraine might achieve membership of the European Union. One union official says that, given the current situation in Ukraine, it will get a "negative response".

Natasha Loder

\section{Berlin places genomics among top funding priorities}

Munich

Research in Berlin that is supported by the German capital is to be focused on twelve areas — including genomics. The areas have been identified by an expert panel as reflecting the city's scientific strengths.

Ingolf Hertel, the state secretary for research in the Berlin ministry of science, has also announced plans to increase competition for funds between universities and research institutes. A small percentage of the DM3.5 billion (US $\$ 1.8$ billion) annual budget for institutional funding of science and education will be distributed competitively.

Both moves are intended to improve the quality of publicly funded research and the effectiveness with which research funds are used. Priority areas include molecular medicine and genome research, information technology, transport research, material research, optics, Earth sciences, applied mathematics and social studies.

The topics were selected by the so-called strategy forum on science, research and

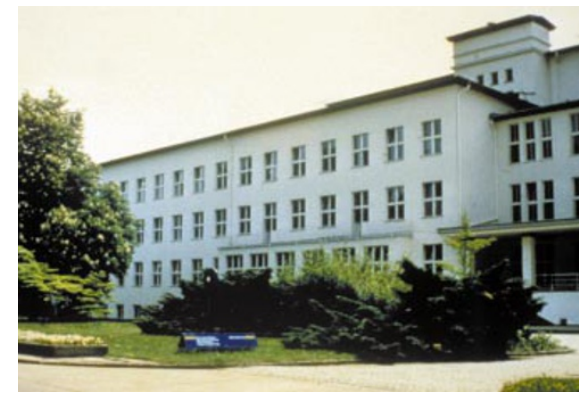

Hotspot: a laboratory building of the Max Delbrück Centre for Molecular Medicine.

innovation. This was set up in January by university presidents, science ministry officials and representatives from industry and from the large science and technology centres Buch and Adlershof.

Since reunification, Berlin has become one of Germany's scientific hotspots, and now hosts three universities and 38 research institutes. But the science budget of the formerly isolated — and heavily subsidized - city has fallen by several hundred million Deutschmarks since 1990 as subsidies from the federal government have been cut.

"Re-modelling Berlin's scientific landscape under constant budgetary constraints was, and is, a notoriously hard job," says Hertel. "Streamlining research and enlarging technology foresight will therefore be major political priorities in the next years."

But he adds that the ministry has no desire to dictate the kind of research scientists should do. "The new funding concept will be worked out jointly with the scientific community," he says.

Hans Lehrach, director of the Berlinbased Max Planck Institute for Molecular Genetics, hopes the new scheme will boost genome research in Berlin. Together with other leading genomics researchers, Lehrach has drafted a proposal for an interdisciplinary genome research centre that would bring together the various aspects of genome research carried out in Berlin. Quirin Schiermeier 